C JBSSR/AIM, 2018, ISSN: 2542-2812.

\title{
Contribution of E-Marketing for the Income Generation in Travel Agencies of Nepal
}

\author{
Parbat Humagain ${ }^{1}$
}

\begin{abstract}
The major objective of this study is to examine the relationship between internet marketing usage and its contribution for the income generation in travel agencies of Nepal. The research is descriptive in nature and is an applied research. The research is based on quantitative data. The populations for the study are the basically owners, chairman and managers of travel agencies and the sample size consists of 120 respondents. The data for the research are collected through primary source of data collection method that includes questionnaire. The research is also carried out with the help of secondary data as we need to study related theories to make research more insightful. Descriptive as well as inferential analyses have been done for the data to be analyzed. Frequency tables are analyzed through SPSS 16.0 and are used for descriptive analysis. Chi- Square test, and Hypothesis Testing (t-test) and Correlation have been done for inferential analysis. The data analysis is of cross sectional in nature. The survey resulted that, there is a strong correlation between internet marketing uses and increase in return on equity, increase in average sales volume and general increase in company income in travel agencies of Nepal. There exists a strong correlation between increases in return on equity and reduction in operating costs, increase average sales volume and general increase in profit margin of the business. From the research, it is noted that there are several benefits obtained from incorporating the internet in marketing strategies. Therefore, the travel agencies should utilize more internet marketing methods and try to incorporate the internet in all their marketing strategies in order to fully enjoy the benefits of internet marketing. Since internet coverage is increasing through the introduction of mobile internet, marketing on the internet becomes a critical factor concerning the company income.
\end{abstract}

Keywords: technological competence, internet marketing, perceive benefits, primary survey and descriptive statistics.

\footnotetext{
Mr.Humagain is working at MAW Enterprises Pvt. Ltd. as an Assistant Manager in Business Development Unit, Kathmandu

Corresponding Email: parbat.humagain2013@gmail.com
} 


\section{Introduction}

Nepal, which has tremendous natural resources, is a destination for tourists. The major lacking behind its development and popularity is due to poor management and marketing strategies. E- Marketing can be the best approach to promote our country and for the growth of the tourism industry based in our country. Today pushing promotions in Face book seems more effective than to push full page promotions in national daily. The global use of the internet is creating the opportunities to enhance efficiency and effectiveness of today's firms. It is widely accepted that

Information and communication technologies such as the internet are rapidly expanding and have affected the way businesses are performed and the way organizations compete. The Tourism industry makes use of a diverse range of information and a main user of these technologies. The technologies have affected the way tourism industries conduct their business and, in particular, the way organizations market their tourism products. The use of the internet as a marketing tool has progressed daily since its inception. Over the last decade organizations in all sectors of the economy rushed to join the online business community and adopted the internet in their daily business activities. The maximum use of internet offers opportunities for tourism firms to expand their customer base, build communication with customers and related partners in a more cost effective way. The major objective of this study is to examine the relationship between internet marketing usage and its contribution for the income generation in travel agencies of Nepal.

This research will facilitate in recognizing the gap that exists due to the absence of general consensus on the relationship between e-commerce usage and business growth and absence of extensive literature on the impact internet utilization in Nepalese tourism industries. Therefore, this study provides information on the relationship between internet marketing usage and income of tourism industries in Nepal.

i) How internet marketing contributes on the income of the Tourism industries?

ii) Is there a significant relationship between internal, external factors and organizational growth via internet marketing usage?

From the descriptive statistics, we found that using internet is the most important factor to reach new customer, to expand business globally and to keep pace with existing competition. The least important objective came out in reducing advertising cost of the company. 
While analysing the perception of respondents towards the internet usage, it was found all of the eight criteria have got higher mean. From the t-test, it was found that, there is a significant relationship between having an own website and increase in return on equity, reduction in operating costs, increase in average sales volume, rise in profit margin, reaching markets easily, reduction in advertising costs, ability to increase sales volume, improvement in marketing communication, increase in competitive advantages, effective partnerships with partners and enhance customer satisfaction.

The survey resulted that there is a strong correlation between alliances are a source of information on internet marketing and alliances improve our proficiency, increase in return on equity, increase in average sales volume and general increase in profit margin. There exists a strong correlation between increases in return on equity and reduction in operating costs, increase average sales volume and general increase in profit margin of the business.

\section{The Review of Literature}

Williams and Palmer (1999) conducted a research on "Tourism destination brands and electronic commerce: Towards synergy" and the result showed that the adoption of electronic distribution channels throughout the Western Australian tourism industry has been very fragmented. Linh (2012) conducted a research on "Practice of internet marketing in destination branding" and the survey showed that destination branding plays an important role in destination's tourism development. Soteriades, Aivalis and Varvaressos (2004) conducted a research on "E-marketing and e-commerce in the tourism industry: a framework to develop and implement business initiatives." The study showed that the Information technology leads to flexible and market-oriented business, and success depends on quick response to rapidly changing customer needs, using ICT in order to deliver the appropriate products to the targeted segments.

Standing and Vasudavan (2000) conducted a research on "Diffusion of internet technologies in travel agencies in Australia." The results highlighted that a significant number of travel agencies have adopted the use of the WWW but most of them only use a fraction of its business potential. Bennett and Lai (2005) conducted a research on "The impact of the internet on travel agencies in Taiwan" and found that the travel agencies are aware of the importance of the internet usage. Buhalis (2005) conducted a research on "The strategic impact of the internet on the tourism industry" and came to find that the emergence of the Internet altered the structure of the travel industry.

Barnett and Standing (2000) conducted a research on "Repositioning travel agencies on the internet." The study showed that the virtual business models 
applied to the travel sector presents a much greater spectrum of possibilities and opportunities for travel agencies exploring online ventures.

Buhalis and Deimezi (2004) conducted a research on "E-tourism developments in Greece: Information communication technologies adoption for the strategic management of the Greek tourism industry". The result of this research indicates that the tourism business sector is lagging behind the opportunities in the rapid changing environment.

Wang and Cheung (2004) conducted a research on "E-Business adoption by travel agencies: Prime candidates for mobile e-business" and found that e-business adoption is affected by both internal and external factors. Seven factors were examined at the environmental, organizational, and managerial levels. All of them, except for institutional pressure, had significant effects on the intention to adopt ebusiness or the implementation of e-business. Munoz and Amaral (2010) conducted a research on "Internet usage for travel and tourism: The case of Spain." The result showed that the Internet usage for travel related purposes is heavily dependent on the Internet penetration rate.

Oppermann (2009) conducted a research on "Database marketing by travel agencies" and the study showed that the travel agencies were involved only to a limited extent in the three identified areas of database marketing: customer retention, product promotion, and customer creation. Abou-Shouk et. al. (2012) conducted a research on "Internet adoption by travel agents: A case of Egypt" and from the analysis, it is found that $66 \%$ of all Egyptian TAs do not have a website, whereas $40.8 \%$ of TAs Category (A) has websites.

Alipour, Hajaliakbari and Javanbhakht (2011) conducted a research on "The impact of web-marketing mix (4s) on the development of tourism industry in Iran" and the findings show that there is a significant relationship among all variables. Also, investigating the variables' relationships show that all aspects of independent variables of $4 \mathrm{~s}$ marketing mix model as scope, site, synergy and system have significant relationship with developing tourism industry.

Arya (2013) conducted a research on "The role of internet marketing in Finnish tourism industry, according to the research findings, Internet marketing is nowadays the main way of marketing within the companies in the tourism industry.

Seliat (2017) conducted a research on "The effect of the growth of electronic commerce on the tourism development in Nigeria," and the research showed that the first online travel company have been successful since they started.

Abou-Shouk et al. (2012) conducted a research on "Internet adoption by travel agents: A case of Egypt" and from the analysis, it is found that $66 \%$ of all 
Egyptian TAs do not have a website, whereas $40.8 \%$ of TAs Category (A) has websites.

\section{The Methodology}

\subsection{The Basic Model}

Internet is being an integral part of every business. We cannot imagine a single minute without internet. Along with, its development and application in tourism have attracted the attention of many researchers in both developed and developing nations. Many efforts have been devoted to establish the relationship between internet application and business performance. However, researchers have not yet reached a general conclusion on the impact of e-commerce or internet applications on business performance. This implies that the impact of internet applications on business performance is still debatable and should be further researched.

While it is obvious that the Nepalese hospitality sector has not been left behind in adopting internet, as it is evident from numerous hospitality properties that have established their presence on the internet, it is not clear yet whether the spread and utilization of internet marketing has supported the growth of the Nepalese hospitality businesses. This is due to the fact that most previous studies concentrated on the role and utilization of the internet in the tourism industry without considering its effects on business performance and growth. This makes it difficult to establish the real relationship between internet marketing usage and hospitality performance in Nepal. Thus, this study emanated from the gap that exists due to the absence of general consensus on the relationship between ecommerce usage and business growth and absence of extensive literature on the impact internet utilization in Nepalese tourism industries.

The framework below shows a relationship between dependent variables and independent variables. In this study, the proposed theoretical model is derived from the basic model, various literature reviewed above and concept from books. The study is based on two assumptions: the level of internet marketing usage is depended upon various internal and external factors and that, internet marketing usage significantly influence business profitability.

The framework developed by Salwani et al. (2009) for their study on "E-commerce Usage and Business Performance in the Malaysian Tourism Sector" serves as a basis for this research and it has helped in analyzing and interpreting the empirical results. 


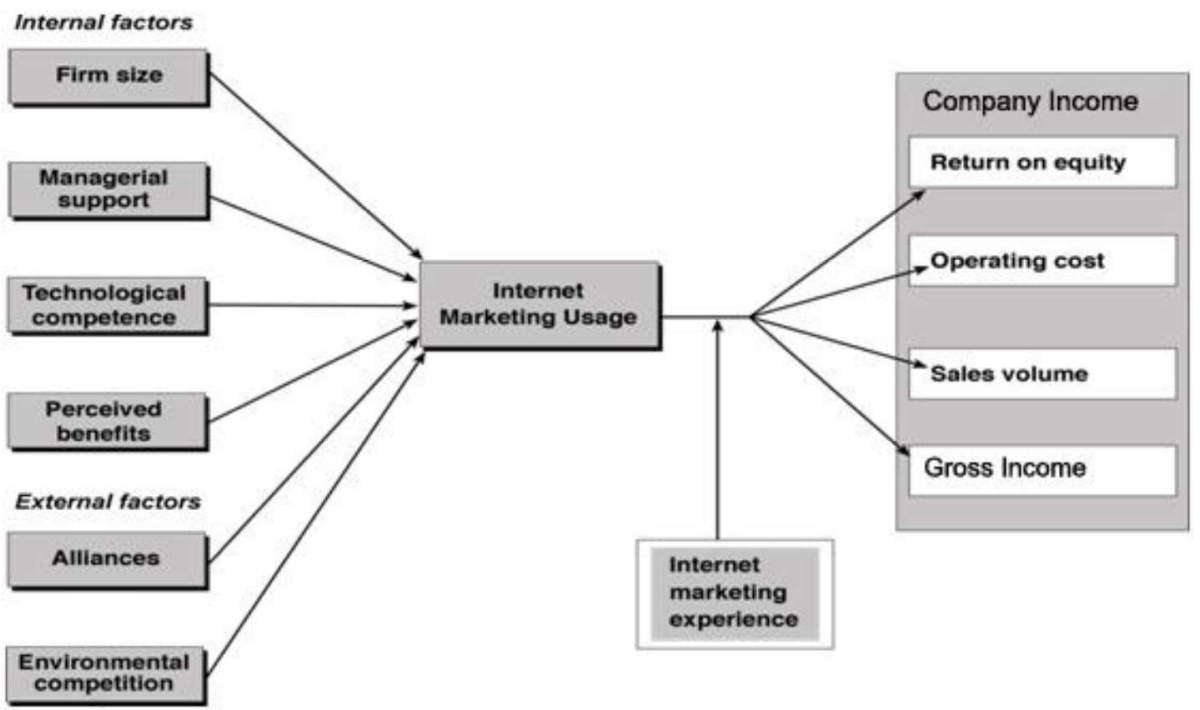

Figure 1: Conceptual Framework

\section{Specification of the variables}

\section{Firm size and internet marketing use}

Firm size is one of the factors that can influence internet marketing spending as well as the sales of a firm. Large firms are more likely to benefit from the use of ecommerce than smaller ones, in view of the fact that they have more resources than smaller ones.

\section{Top management support and internet marketing use}

A number of studies indicate that top management support is the most critical factor in determining the successful use of e-commerce. Top management commitment is one of a small set of organizational factors which constantly reappear as significantly related to the successful use of information technologies.

\section{Technological competence and internet marketing use}

Competence is the acquisition of knowledge, skills and abilities at a level of expertise, sufficient to be able to perform in an appropriate work setting. Technological resources are an important factor for successful internet adoption, especially as a strong backing of e-commerce usage. In this research, technological competence refers to the IT personnel that enable the development and implementation of internet marketing. If the IT personnel have sufficient training in 
the ways to use the internet, then implementing internet marketing could be successful.

\section{Perceived benefits and internet marketing use}

One of the factors that can affect the adoption and use of the internet is the perceived benefits of using such technology. The adoption of e-commerce is largely based on perceived benefits. Perceived benefits can be direct, such as cost saving, an increase in sales volume and an increase in number of new customers or indirect such as convenience and the building of customer loyalty. In this study, perceived benefits which were considered are: the ability of the internet to reach global markets and increase in sales volume and convenience.

\section{Existence of alliances and internet marketing use}

Alliances can take on a number of forms and include personal contact networks, social networks, business networks and marketing networks. In this study, alliances refer to the extent to which travel agencies use business associates or contact networks as a resource to plan and implement their internet marketing strategies.

\section{Environmental competition and internet marketing use}

Research literature supports that the decision to engage in a particular behavior, depends on what is happening in the environment at that particular moment. Competitive pressures and customer pressure make up external drivers that can influence the adoption of internet marketing.

\section{Internet marketing usage and business growth}

The overall objective of using internet marketing is to maximize profit. The firms that use e-commerce are more likely to assess their innovations as having high positive impacts on firm performance than those without e-commerce.

\section{Return on Equity}

As per the research I found that all most all the travel agencies using internet marketing have significant support on the equity. After using the internet, the return on the investment is increasing.

\section{Operating Cost}

One simple example in today's digital world giving an advertisement on renowned national daily is far more expensive in cost as well as in reach of the advertisement. So from the research I found most of the travel agencies have saved their operating cost because of internet marketing. 


\section{Sales Volume}

Talking about the benefits of e-marketing on sales volume, the research indicates that the travel agencies implementing internet for their sales promotion have doubled their sales volume as the internet promotion have multiple reach than that of other promotions.

\section{Gross Income}

The research shows that using internet on marketing had played a vital role in increasing the gross income of the business.

Previous experience with internet marketing is a vital factor in the successful utilization of this technology, that experience in the use of e-commerce will have a strong contingent effect on the relationship between e-commerce usage and business financial performance. The experience in e-commerce is an important factor which determines usage and business financial performance.

\subsection{The Data}

This study is focused on understanding the impact of e-marketing on the growth of travel agencies in Nepal. Therefore, a quantitative and applied research methodology has been used.

In this study, both primary and secondary data are used. The primary data were collected through the distribution of questionnaire. Similarly, secondary data were collected from journal, articles, and magazines and similar surveys done by other organizations. The research survey was carried out within Kathmandu valley which covers cities like Kathmandu, Lalitpur, and Bhaktapur. Total population (N) for the study were travel agencies Owner/ Chairman and/Top Employees of Kathmandu valley who are using the internet and the sample size (n) were 120 respondents. The sampling units for this study were male and female.

Data collection technique was used through questionnaire which consisted of number of questions related to the internet usage and its impact on the growth of the firm. The data was collected by the researcher by visiting different locations in the valley and was collected in a specific time period of 10-15 days. The data was collected from primary as well as secondary sources of data collection. For primary data collection structured questionnaires has been prepared and distributed in different travel agencies to different employees. The secondary data was collected through internet, journals, books, magazines and related research papers. Based on the collected data, necessary analysis, recommendations and generalizations have been made. 
For the validity and reliability, the objectives of the research were reviewed and review of literature was done as many as possible. Expert consultation and pretesting were done for the validity of the primary source that is questionnaire. Some cross-check questions were also included to check the reliability of the result. Also, it was used the researcher administered questionnaire for the purpose of reliability.

\subsection{Data Analysis Methods}

For data management, SPSS 15.0 software has been used. The collected data were logically and systematically recorded using SPSS software and analysis was done as per the requirement of research. Descriptive analysis, as well as inferential analysis was used for analyzing the data. Central tendency, frequency table, and dispersion were used for descriptive analysis, whereas; hypothesis testing, chisquare test, t-test, ANOVA tests and other testing were done for inferential analysis.

\section{Results and Discussion}

\subsection{Descriptive Statistics Analysis}

From the descriptive statistics, we found that reach new customer is the most important objectives of using in the business with mean of 2.08 , and standard deviation of 1.089 .

Second important objective came out to be market globally with mean of 2.13, and standard deviation of 0.961 . Third important objective came out to be keep pace with competition with mean of 2.83 and standard deviation of 1.072. The least important objective came out to be reducing advertising cost with a mean of 2.95 and standard deviation of 1.076 .

Table 1: Descriptive Statistics for Single Responses

\begin{tabular}{llllll}
\hline Marketing Objectives & N & Minimum & Maximum & Mean & Std. Deviation \\
\hline Reach new customers & 120 & 1 & 4 & 2.08 & 1.089 \\
Market globally & 120 & 1 & 4 & 2.13 & 0.961 \\
Keep pace with competition & 120 & 1 & 4 & 2.83 & 1.072 \\
Reduce advertising cost & 120 & 1 & 4 & 2.95 & 1.076 \\
\hline
\end{tabular}

While analysing the perception of respondents towards the internet usage, it was found all of the eight criteria have got higher mean than 4, showing that respondents perceive that all the criteria have got a considerable no. of usage, when using the internet. In all eight criteria, to sell services has got highest mean (6.49) followed by to build customer connections, and to find out about competitors got the least mean (4.73). 
Table 2: Descriptive Statistics for Single Responses

\begin{tabular}{llllll}
\hline & N & \multicolumn{3}{l}{ Minimum Maximum Mean Std. Deviation } \\
\hline Find out about competitors & 120 & 2 & 7 & 4.73 & 1.346 \\
Purchase services & 120 & 2 & 7 & 4.74 & 1.126 \\
Find out about suppliers & 120 & 2 & 7 & 5.08 & 1.066 \\
Set up web page & 120 & 2 & 7 & 5.51 & 1.195 \\
Find out about customers & 120 & 3 & 7 & 6.15 & 1.018 \\
$\begin{array}{l}\text { Provide services } \\
\text { information }\end{array}$ & 120 & 3 & 7 & 6.26 & 0.903 \\
$\begin{array}{l}\text { Build customer } \\
\text { connections }\end{array}$ & 120 & 4 & 7 & 6.3 & 0.784 \\
Sell services & 120 & 4 & 7 & 6.49 & 0.722 \\
\hline
\end{tabular}

\subsection{Inferential Analysis}

The independent t-test is an inferential statistical test that determines whether there is a statistically significant difference between the means in two unrelated groups. These types of t-tests are used to compare groups of participants that are not related in any way. This test is used in this study to compare the means of two independent groups in order to determine whether there is statistical evidence that the associated population means are significantly different.

Table 3: Independent Sample t-test by Technological Competence

\begin{tabular}{|c|c|c|c|c|c|c|}
\hline Statistics & Gender N & Mean & $\begin{array}{l}\text { Std. } \\
\text { Dev. }\end{array}$ & $\mathbf{T}$ & Sig. & Result \\
\hline Availability of skillful labor with & Male 95 & 3.87 & 0.467 & \multirow{2}{*}{-0.8} & \multirow{2}{*}{0.427} & \multirow{2}{*}{ Accept } \\
\hline both IT and travel knowledge & Female 25 & 3.96 & 0.539 & & & \\
\hline Provides sufficient training to & Male $\quad 95$ & 3.59 & 0.751 & \multirow{2}{*}{-0.29} & \multirow{2}{*}{0.775} & \multirow{2}{*}{ Accept } \\
\hline IT personnel for internet marketing & Female 25 & 3.64 & 0.907 & & & \\
\hline $\begin{array}{l}\text { Utilizes the internet more than } \\
\text { other marketing communication tools }\end{array}$ & Male & 3.96 & 0.698 & 1.21 & 0.228 & Accept \\
\hline
\end{tabular}

From table 3, we can conclude that there is no significant relationship between availability of skillful labor with both IT and travel knowledge, sufficient training to IT personnel for internet marketing and utilizing the internet more than other marketing communication tools with respect to gender. 
Table 4: Independent Sample t-test by Profitability

\begin{tabular}{|c|c|c|c|c|c|c|c|}
\hline Statistics & $\begin{array}{l}\text { Own } \\
\text { Website }\end{array}$ & $\mathbf{N}$ & Mean & $\begin{array}{l}\text { Std. } \\
\text { Dev. }\end{array}$ & $\mathbf{T}$ & Sig & Result \\
\hline \multirow{2}{*}{ Increase in Return on Equity } & Yes & 106 & 4.2 & 0.542 & 4.424 & 0 & \multirow{2}{*}{ Reject } \\
\hline & No & 14 & $\begin{array}{l}3.5 \\
4.21\end{array}$ & $\begin{array}{l}0.65 \\
0.643\end{array}$ & & \multirow[b]{2}{*}{0} & \\
\hline Reduction in Operating Costs & $\begin{array}{l}\text { Yes } \\
\text { No }\end{array}$ & $\begin{array}{l}106 \\
14\end{array}$ & $\begin{array}{l}4.21 \\
3.29\end{array}$ & $\begin{array}{l}0.643 \\
0.825\end{array}$ & 4.87 & & Reject \\
\hline \multirow{3}{*}{$\begin{array}{l}\text { Increase in Average Sales } \\
\text { Volume } \\
\text { General Increase in Profit } \\
\text { Margin }\end{array}$} & Yes & 106 & 4.26 & 0.557 & \multirow{2}{*}{3.091} & \multirow{2}{*}{0.002} & \multirow{2}{*}{ Reject } \\
\hline & No & 14 & 3.79 & 0.426 & & & \\
\hline & Yes & 106 & 4.39 & 0.562 & 3.564 & 0.001 & Reject \\
\hline
\end{tabular}

From the t-test, it was found that, there is a significant relationship between having a own website and increase in return on equity, reduction in operating costs, increase in average sales volume, and general rise in profit margin, reaching markets easily, reduction in advertising costs, ability to increase sales volume, improvement in marketing communication, increase in competitive advantages, effective partnerships with suppliers/partners, and enhance customer satisfaction.

From the research I am well aware regarding the fruitful benefits of using internet in promotion of travel agency business. So I like to recommend all the travel agencies to implement E-marketing on their business as it gives you a multiple advantages with good return on investment and keeps on increasing the business profitability in the days to come.

\section{Concluding Remarks}

According to research finding, Internet marketing is, nowadays, the main way of marketing within the companies in the tourism industry. Internet marketing phenomenon is seen to be a fast growing and constantly developing. The findings showed that Internet marketing is seen to be more profitable for the companies and it is a relevant tool in order to keep up with market competition. The results demonstrated that the Internet marketing is at the moment the most cost effective way of marketing.

The companies within the tourism industry are satisfied with having the power to be able to measure and modify their marketing anytime. Internet marketing allows companies to track, how their marketing is progressing, how people are finding them and also who these potential customers are. It is possible for companies to effortlessly analyze their customer behavior. Internet marketing is giving the companies the chance to target a wider group of customers and get closer with them. In addition customers as well, nowadays, have the ability easily to reach service providers, compare services, find information and even share their own experiences on the Internet. The results showed that website advertising is the most 
important tool for the companies, nowadays, to be reachable and visible and most of the travel agencies bookings are done from the internet. The most important objective using internet in business came out to be reach new customer followed by market globally.

The survey resulted that, there is a significant relationship between having a own website and increase in return on equity, reduction in operating costs, increase in average sales volume, and general rise in profit margin, reaching markets easily, reduction in advertising costs, ability to increase sales volume, improvement in marketing communication, increase in competitive advantages, effective partnerships with suppliers/partners, and enhance customer satisfaction.

From the research findings and empirical literature, it was noted that there are several benefits obtained from incorporating the internet in marketing strategies. Unfortunately it was discovered that not all travel agencies utilize most of the common internet features for marketing. The study reveals that those properties which utilize more internet features for marketing tend to realize an increase in business profitability. Therefore, it is also advised that travel agencies should utilize more internet marketing methods and try to incorporate the internet in all their marketing strategies in order to fully enjoy the benefits of internet marketing.

From the research findings, it is observed that not all employees who perform marketing activities have obtained formal training on how to use the internet for marketing purposes. It is, therefore, recommended that travel agencies must invest in training activities so that their personnel are able to keep pace with the changes in internet features which can be exploited for marketing as well as equipping them with the necessary skills needed for internet marketing. Travel agencies are also recommended to hire IT personnel with appropriate knowledge and skills of using internet if possible.

The research established that internet marketing usage depends on the support and commitment of top management. It is also noted that those properties which agree that their managers give advice on how to use internet marketing, tend to utilize internet marketing more than other marketing tools. In this regard, it is recommended that for a property to fully realize the benefits of internet marketing, top management should support the use of this tool through giving advice as well as providing the necessary resources required for implementing internet marketing.

It is noted in the research that some of the travel agencies do not make use of alliances or business associates to access knowledge on how to market over the internet. It is, therefore, recommended that travel agencies should make use of services from alliances in order to effectively understand internet marketing and to fully utilize it. 
Further research is needed on the suppliers and consumers perceptions of the impact of the internet on the travel industry. In addition, a comparison of different countries would be valuable to assess how the impact of the internet varies according to geography. Such further research will provide a much needed complete understanding of the impact of the internet in general and on travel agencies in particular.

\section{References}

Abou-Shouk, M., Lim, W. M., \& Megicks, P. (2012). Internet adoption by travel agents: A case of Egypt. International Journal of Tourism Research, 15, 298312.

Alipour, M., Hajaliakbari, F., \& Javanbakht, N. (2011). The impact of webmarketing mix (4s) on development of tourism industry in Iran. International Journal of Business and Social Science, 2, 267-274.

Armesh, H., Salarzehi, H., Yaghoobi, N. M., Heydari, A., \& Nikbin, D. (2010, November). Impact of online/internet marketing on computer industry in Malaysia in enhancing consumer experience. International Journal of Marketing Studies, 2, 75-86.

Barnett, M., \& Standing, C. (2000). Repositioning travel agencies on the internet. Journal of Vacation Marketing, 7, 143-152.

Bennett, M. M., \& Lai, C.-W. K. (2005). The impact of the internet on travel agencies in Taiwan. Tourism and Hospitality Research, 6, 8-23.

Buhalis, D., \& Deimezi, O. (2004). E-tourism developments in Greece: Information communication technologies adoption for the strategic management of the Greek tourism industry. Tourism and Hospitality Research, 5, 103-130.

Buhalis, D., \& Zoge, M. (2005). The strategic impact of the internet on the tourism industry. Tourism and Hospitality Research, 481-492.

Kaynama, S. A., Black, C. I., \& Keesling, G. (2003). Imapct of the internet on internal service quality factors: The travel industry case. Journal of Applied Business Research, 19, 135-146.

Lagrosen, S. (2005). Effects of the internet on the marketing communication of service companies. Journal of Services Marketing, 19, 63-69.

Linh, D. T. (2012). Practice of internet marketing in destination branding. International Journal of Tourism Research, 3, 67-76. 
Munoz, T. G., \& Amaral, T. P. (2010). Internet usage for travel and tourism: The case of Spain. 21st European Regional International Telecommunications Society Conference (pp. 1-22). Copenhagen.

Prasad, V. K., Ramamurthy, K., \& Naidu, G. M. (2001). The influence of internetmarketing integration on marketing competencies and export performance. Journal of International Marketing, 9, 82-110.

Soteriades, M., Aivalis, C., \& Varvaressos, S. (2004). E-marketing and ecommerce in the tourism industry: A framework to develop and implement business initiatives. Tourism Today, 20.

Standing, C., \& Vasudavan, T. (1999). Internet marketing strategies used by travel agencies in Australia. Journal of Vacation Marketing, 6, 21-32.

Standing, C., \& Vasudavan, T. (2000). Diffusion of internet technologies in travel agencies in Australia. Journal of Vacation Marketing, 2, 231-233.

Tsiotsou, R. H., \& Vlachopoulou, M. (2011). Understanding the effects of market orientation and e-marketing on service performance. Marketing Intelligence and Planning, 29, 141-155.

Vich-i-Martorell, G. A. (2004). The internet and tourism principals in the Balearic Islands. Tourism and Hospitality Research, 5, 25-44.

Wang, S., \& Cheung, W. (2004). E-Business adoption by travel agencies: Prime candidates for mobile e-business. International Journal of Electronic Commerce, 8, 43-63.

Williams, A., \& Palmer, A. J. (1999, March 8th). Tourism destination brands and electronic commerce: Towards synergy? Journal of Vacation Marketing, 5, 263-275. 